\title{
PREDICTING INSULIN RESISTANCE USING THE TRIGLYCERIDE-TO-HIGH DENSITY LIPOPROTEIN RATIO IN EGYPTIAN ADULTS
}

\author{
Fared F. Abd El Hafez, Mohamed S.S. Saad ${ }^{1}$, Hatem M. Salem ${ }^{I}$, Ayman Abd-Elrahman M.N , Fawzy A. El- \\ Messallamy ${ }^{1}$ \& Asmaa M. Esh ${ }^{2}$ \\ ${ }^{1}$ Internal Medicine Department, Faculty of Medicine, Zagazig University, Egypt. \\ ${ }^{2}$ clinical Pathology Department, Faculty of Medicine, Zagazig University, Egypt
}

\begin{abstract}
Background: There are several directly and indirect methods to assess insulin resistance. The gold standard method was the hyperinsulinemic-euglycemic clamp (glucose clamp) technique. Although HOMA (homeostatic model assessment) IR has been widely used in study of metabolic syndrome, Lack of standardized insulin assay has limited it is clinically assay. Triglycride-TO-High Denisity Lipoprotein ratio (TG/HDL) has been advocated as simple clinical indicator of insulin resistance, also it has been evaluated as predictor of diabetes and coronary heart disease.
\end{abstract}

Aim of the Work: To develop simple predictive method to evaluate insulin resistance using TG and HDL.

Patient and Methods: A total of 95 person were included in this study and divided in to five groups as follow: Group (1): 19 healthy Persons aged $45.4 \pm 11.2$, Group (2): 19 Non diabetic high risk patients without cardiovascular complication aged $56.9 \pm 10.5$, Group (3): 19 Non diabetic with high risk patients with cardiovascular complication aged $62.2 \pm 13.7$, Group (4): 19 Diabetic patients without cardiovascular complication aged $60 \pm 16.7$ and Group (5): 19 Diabetic patients with cardiovascular complication aged 63.9 \pm 12.2. All subjects were subjected to the following: Full history taking, full general examination, BMI, Waist circumference, HbA1C, Triglyceride, total cholesterol, HDL-C, LDL-C. Fasting insulin, Fasting blood sugar and HOMA-IR.

Results: the highest percentage of HOMA among the studied groups was in group $5(94.7 \%)(5.8 \pm 2.6, \mathrm{P}<$ $0.001)$ followed by group $4(78.9 \%)(3.3 \pm 1.2, \mathrm{P}<0.001)$ then group $3(5.3 \%)(1.52 \pm 0.55, \mathrm{P}<0 . \overline{0} 01)$ then other groups. There were highly significant positive correlation between HOMA \& TG/HDL in group $4 \& 5$ (P $<0.05$ ) and insignificant correlation in group $1,2 \& 3$.

Conclusions: There is a significant association between HOMA- IR and TG/HDL ratio suggesting that elevated TG/HDL ratio can be used to predict the presence of insulin resistance.

Keyword: Metabolic syndrom, Insulin resistance, Dyslipidemia, Diabetes

Corresponding author: Fawzy A. El-Messallamy

Received:

1 September 2015

Tel: 010068799998 .

Accepted:

30 September 2015

Email: fawzymessallamy@yahoo.com

\section{INTRODUCTION}

D iabetes Mellitus (DM) is an interesting and complicated systemic disease. The World Health Organization defines DM as a metabolic disorder of multiple etiologies characterized by chronic hyperglycemia (raised glucose concentration) with disturbances of carbohydrate, fat and protein metabolism resulting from defects in insulin secretion, insulin action, or both Diabetes mellitus is classified into: Type I diabetes, Type II diabetes, Gestational diabetes mellitus (GDM), and Other specific types of diabetes mellitus ${ }^{[1]}$.

The World Health Organization (WHO) estimated that the global prevalence of DM would rise from $2.8 \%$ (171 million) to $4.4 \%$ (366 million) by 2030, with the most significant increases predicted in developing countries1. The development of DM immediately increases the patient's propensity to develop a number of irreversible acute and chronic complications. For example, diabetic ketoacidosis is acute complications while chronic complications include macrovascular and microvascular complications. The macrovascular complications include cerebrovascular disease, coronary heart disease, and peripheral vascular disease. The microvascular complications include diabetic retinopathy (DR), diabetic neuropathy, and diabetic nephropathy ${ }^{[2]}$.

Metabolic syndrome is characteristically defined as clustering condition of cardiovascular risk factor including hyperglycemia, dyslipidemia, hypertension, central obesity. It is strongly associated with increase risk in developing diabetes and cardiovascular disease. Path physiology of metabolic syndrome remains subject of 
controversy but many of it is feature associated with insulin resistance ${ }^{[3]}$.

Insulin resistance is a condition in which the body produces insulin but does not use it effectively. When people have insulin resistance, glucose builds up in the blood instead of being absorbed by the cells, leading to type 2 diabetes or prediabetes ${ }^{[4]}$.

Insulin resistance is typically defined as decreased sensitivity or responsiveness to metabolic actions of insulin. Currently, there are several directly and indirect methods to assess insulin resistance. The gold standard method was the hyperinsulinemic-euglycemic clamp (glucose clamp) technique, originally developed by DeFronzo However, the method is complex and time consuming, making it not feasible for either epidemiological investigations or routine clinical applications. Therefore, a number of surrogate indices of insulin resistance have been developed. Previous studies have shown that insulin resistance scores based on the homeostasis model assessment (HOMA) method was strongly correlated with glucose clampassessed insulin resistance ${ }^{[5]}$.

Although HOMA IR has been widely used in study of metabolic syndrome, Lack of standardized insulin assay has limited its clinically assay. It would be considerable benefit for clinicians if other standardized measures are available for prediction insulin resistance without need for direct measurement of fasting insulin since hypertriglyceridemia and low high density lipoprotein cholesterol are two key metabolic abnormalities associated with insulin resistance ${ }^{[6]}$.

TG/HDL has been advocated as simple clinical indicator of insulin resistance, also it has been evaluated as predictor of diabetes and coronary heart disease $^{[7]}$.

In addition, depending on ethnicity different threshold of TG/HDL has been proposed for predicting insulin resistance. Ratio of 3 was suggesting for non Hispanic white and Mexican American and 2 for non Hispanic black and 2.5 for African American ${ }^{[8]}$.

Despite of numerous study have evaluated for optimal threshold of TG/HDL, no study specifically compared the accuracy of TG/HDL with and without clinical and demographic factors in predicting insulin resistance.

\section{AIM OF THE WORK}

We performed this study to develop simple predictive methods on clinical tool evaluating insulin resistance using only routinely collected blood test such as TG and HDL.

\section{SUBJECTS AND METHODS}

This is across sectional study had been carried out at Internal Medicine and Clinical pathology departments in Zagazig University it included 95 patients who had been admitted in the period from March 2012 to October 2012 the included study subjects were divided into five groups:

\section{Group1: Healthy persons (control):}

This group included 19 healthy persons among them 12 males and 7 females their ages ranged from $(30-75)$ years, with normal glycemic parameters and no evidence of cardiovascular diseases.

\section{Group 2: Non diabetic high risk patients without cardiovascular complication:}

This group included 19 patients among them 3 males and 16 females, their ages ranged from $(40-85)$ years ,these were having normal glycemic parameters and one or more of the risk factors for cardiovascular complication but without evidence of these complication.

\section{Group 3: Non diabetic high risk patients with} cardiovascular complication:

This group included 19 patients among them 10 males and 9 females their ages ranged from (35 - 83) years, these were having normal glycemic parameters and one or more of the risk factors for cardiovascular complication with evidence of these complication including (cerebrovascular disease, and coronary heart disease).

\section{Group 4: Diabetic patients without cardiovascular complication:}

This group included 19 diabetic patients among them 5 males and 14 females their ages were ranged from $(35-85)$ years, with no evidence of cardiovascular complication.

\section{Group 5: Diabetic patients with cardiovascular complication:}

This group included 19 diabetic patients among them 5 males and 14 females there ages ranged from $(48-92)$, these were having one or more of the cardiovascular complication including (cerebrovascular disease and coronary heart disease).

\section{Randomization:}


Consequent case admitted to Internal Medicine Department with the above mentioned criteria were included in the study. These were type $2 \mathrm{DM}$ with or without complication or non diabetic patient with high risk to cardiovascular complication and with or without evidence of these cardiovascular complications together with age and sex matched healthy control volunteers from hospital staff.

Exclusion criteria:

Patient with advanced organ failure and Patients who refused to be enrolled in the study or refused to sign the consent. Patient who were on lipid lowering drugs were also excluded.

\section{Ethical clearance:}

Written Informed consent was taken from the patients and control to participate in the study.

\section{Methods:}

Steps of performance and techniques used:

All subjects of this study after fulfill inclusion criteria were subjected to the following assessment.

\section{Full history assessment:}

According to the included sheet Through personal history with special consideration to personal medical history, intake of drugs and smoking, previous history of high blood pressure or diabetes, and symptoms of coronary heart disease, ischemic stroke, or peripheral vascular disease. Family history of high blood pressure, diabetes, coronary heart disease, or dyslipidemia was also ascertained in all participants.

\section{Full general exam:}

With special attention to (Bp, pulse, body temperature, respiratory rate, weight, height, body mass index (BMI) and waist circumference).

Pulse: to show any abnormality

BP: measured after patients admission, it was measured by mercury sphygmomanometer with the subject recumbent in bed with arm supported and positioned at level of the heart after a 10-min rest period, and initially recorded high blood pressure were rechecked at 5-min intervals.

Body mass index (BMI): was calculated by dividing weight (in kilograms) by the square of the height (in meters).
$\mathrm{BMI}=$ weight $\quad$ (in kilograms)/(height (in meters $)^{2}$.

Waist circumference: Waist circumference was measured mid-way between the lateral lower rib margin and the iliac crest ${ }^{(\mathbf{9})}$.

\section{Laboratory investigations:}

They were done according to the methods applied in the clinical pathology and laboratories of Zagazig University hospitals and included:

HbA1C: for long term diabetics control. Triglyceride, total cholesterol, HDL-C, LDLC:

Blood samples were collected after a 12-h overnight fast and deposited in dry tubes with EDTA. The plasma was separated immediately using refrigerated centrifugation at 2,500-3,000 $\mathrm{rpm}$ for a period of $10 \mathrm{~min}$. The samples were processed either immediately or during the first week after processed conservation at $-20^{\circ} \mathrm{C}$.

Optimal LDL cholesterol levels for adults with diabetes are less than $100 \mathrm{mg} / \mathrm{dL}$ (or less than $70 \mathrm{mg} / \mathrm{dl}$ if with cardiovascular complication), optimal HDL cholesterol levels are equal to or greater than $50 \mathrm{mg} / \mathrm{dL}$, and desirable triglyceride levels are less than 150 $\mathrm{mg} / \mathrm{dL}$ and Desirable total Cholesterol Level Less than $200 \mathrm{mg} / \mathrm{dL}$. The TG/HDL ratio was calculated in the following manner: TGs of fasting $(\mathrm{mg} / \mathrm{dL}) / \mathrm{HDL}$-cholesterol $(\mathrm{mg} / \mathrm{dL})$. The cut-off used was 3.0. (Medicine Net.com, July 13, 2012).

Fasting insulin: were measured using human insulin Enzyme Linked Immunosorbent Assay (ELISA) kit.

\section{Fasting blood sugar:}

HOMA (Homeostasis Model Assessment): Insulin resistance was defined by (HOMA-IR). HOMA-IR was calculated by dividing the product of fasting plasma glucose $(\mathrm{mg} / \mathrm{dL})$ and fasting plasma insulin (mU/L) by 405.IR was considered an index of HOMA-IR=>2.69 ${ }^{(\mathbf{1 0})}$.

\section{Statistical Methods:}

All data were coded, checked, entered and analyzed using SPSS Soft ware version 19, P value $<0.05$ was considered statistically significant.

\section{Table (1) shows demographic} characteristics of the five studied groups which demonstrate comparison of (Mean \pm SD) of age and sex. 
Table (2) shows clinical characteristics of the five studied groups which demonstrate that there are statistical significant differences between Means of BMI, waist circumference, systolic and diastolic blood pressure.

$\{\mathrm{P}$ value $(\mathrm{BMI})=0.001, \mathrm{p}$ value (waist circumference $)=<0.001, \mathrm{p}$ value $(\mathrm{SBP})=$ $<0.003 \& \mathrm{p}$ value $(\mathrm{DBF})=<0.001\}$.

Table (3) shows biochemical characteristics of the five studied groups which demonstrate that there are statistical significant differences between Means of biochemical profile.

$\{\mathrm{P}$ value $(\mathrm{FBS})<0.001, \mathrm{p}$ value $(\mathrm{PBG})<$ 0.001 , (with higest level in group 4\&5) $\mathrm{p}$ value (Cholesterol) $<0.003$ (with higest level in group5\&4) $\mathrm{p}$ value (TG) $<0.001$ (with higest level in group 5\&4)p value (HDL) $<0.008$ (with lowest level in group3\&5) p value (LDL) <
$0.001, \mathrm{p}$ value $(\mathrm{TG} / \mathrm{HDL})<0.001$ (with higest level in group5\&4)

Table (4) Parameter of glucose homeostasis of the five studied groups which demonstrate that there are statistical significant differences between Means of insulin, IR \& HBA1C.

$\{\mathrm{P}$ value (insulin) $=<0.001, \mathrm{p}$ value $(\mathrm{IR})=$ $<0.001, \& \mathrm{p}$ value $(\mathrm{HBA} 1 \mathrm{C})=<0.001\}$.

Table (5): show the percentage of HOMA among the studied groups in which the highest percentage was in group $5(94.7 \%)$ followed by group $4(78.9 \%)$ then group $3(5.3 \%)$ then other groups.

Table (6) showed correlation between HOMA \& TG/HDL among studied groups which demonstrate that there are highly significant positive correlation between HOMA $\&$ TG/HDL in group $(4 \& 5)$ and insignificant correlation in group (1-3).

Table (1): Demographic characteristic of the studied groups

\begin{tabular}{lccccc}
\hline Variable & $\begin{array}{c}\text { Group 1 } \\
\text { Mean } \pm \text { SD }\end{array}$ & $\begin{array}{c}\text { Group 2 } \\
\text { Mean } \pm \text { SD }\end{array}$ & $\begin{array}{c}\text { Group 3 } \\
\text { Mean } \pm \text { SD }\end{array}$ & $\begin{array}{c}\text { Group 4 } \\
\text { Mean } \pm \text { SD }\end{array}$ & $\begin{array}{c}\text { Group 5 } \\
\text { Mean } \pm \text { SD }\end{array}$ \\
\hline Age (years) & $45.4 \pm 11.2$ & $56.9 \pm 10.5$ & $62.2 \pm 13.7$ & $60 \pm 16.7$ & $63.9 \pm 12.2$ \\
Range & $30-70$ & $40-80$ & $35-83$ & $35-85$ & $48-92$ \\
\hline Gender & & & & & \\
$\quad$ Male & $12(63.2 \%)$ & $3(15.8 \%)$ & $9(47.4 \%)$ & $4(21.1 \%)$ & $6(31.6 \%)$ \\
$\quad$ Female & $7(36.8 \%)$ & $16(84.2 \%)$ & $10(52.6 \%)$ & $15(78.9 \%)$ & $13(68.4 \%)$ \\
\hline
\end{tabular}

Table (2): Clinical characteristic of the studied groups

\begin{tabular}{|c|c|c|c|c|c|c|c|}
\hline Variable & $\begin{array}{c}\text { Group 1 } \\
\text { Mean } \pm \text { SD }\end{array}$ & $\begin{array}{c}\text { Group } 2 \\
\text { Mean } \pm \text { SD }\end{array}$ & $\begin{array}{c}\text { Group 3 } \\
\text { Mean } \pm \text { SD }\end{array}$ & $\begin{array}{c}\text { Group } 4 \\
\text { Mean } \pm \text { SD }\end{array}$ & $\begin{array}{c}\text { Group 5 } \\
\text { Mean } \pm \text { SD }\end{array}$ & $\begin{array}{c}\text { F test } \\
\text { (ANOVA) }\end{array}$ & $P$ value \\
\hline $\begin{array}{l}\text { Height(m) } \\
\text { Range }\end{array}$ & $\begin{array}{l}1.69 \pm .04 \\
1.58-1.75\end{array}$ & $\begin{array}{c}1.66 \pm .06 \\
1.5-1.75\end{array}$ & $\begin{array}{c}1.66 \pm .06 \\
1.5-1.75\end{array}$ & $\begin{array}{c}1.68 \pm .06 \\
1.5-1.75\end{array}$ & $\begin{array}{c}1.65 \pm .07 \\
1.5-1.75\end{array}$ & 0.67 & 0.61 \\
\hline $\begin{array}{l}\text { Weight }(\mathrm{kg}) \\
\text { Range }\end{array}$ & $\begin{array}{c}74.5 \pm 6.8 \\
60-85\end{array}$ & $\begin{array}{c}81.9 \pm 12.6 \\
60-110\end{array}$ & $\begin{array}{c}82 \pm 13.9 \\
55-115\end{array}$ & $\begin{array}{c}81 \pm 10.6 \\
65-105\end{array}$ & $\begin{array}{c}84.3 \pm 14.3 \\
55-110\end{array}$ & 1.85 & 0.12 \\
\hline $\begin{array}{l}\text { BMI } \\
\text { Range } \\
\end{array}$ & $\begin{array}{c}26.3 \pm 1.7 \\
23-28.8 \\
\end{array}$ & $\begin{array}{l}29.6 \pm 3.1 \\
25.4-35.9 \\
\end{array}$ & $\begin{array}{c}29.6 \pm 3.6 \\
23.4-38 \\
\end{array}$ & $\begin{array}{l}28.9 \pm 2.6 \\
24.2-34.3 \\
\end{array}$ & $\begin{array}{c}30.4 \pm 4.1 \\
23.67-37.2\end{array}$ & 4.8 & 0.001 \\
\hline $\begin{array}{l}\text { Waist } \\
\text { Range }\end{array}$ & $\begin{array}{c}111.1 \pm 6.9 \\
102-125\end{array}$ & $\begin{array}{c}120.1 \pm 4.1 \\
113-130\end{array}$ & $\begin{array}{l}121 \pm 6.2 \\
111-130\end{array}$ & $\begin{array}{c}123.1 \pm 4.6 \\
115-131\end{array}$ & $\begin{array}{c}123.7 \pm 4.9 \\
115-132\end{array}$ & 16.1 & $<0.001$ \\
\hline $\begin{array}{l}\text { pulse } \\
\text { Range } \\
\end{array}$ & $\begin{array}{c}82.7 \pm 6.3 \\
72-92 \\
\end{array}$ & $\begin{array}{c}84.1 \pm 6.1 \\
70-92 \\
\end{array}$ & $\begin{array}{c}84.9 \pm 6.7 \\
75-94 \\
\end{array}$ & $\begin{array}{c}84.5 \pm 6.2 \\
74-96 \\
\end{array}$ & $\begin{array}{c}83.9 \pm 6.8 \\
75-98 \\
\end{array}$ & 0.31 & 0.86 \\
\hline $\begin{array}{l}\text { SBP }(m m H g) \\
\text { Range }\end{array}$ & $\begin{array}{c}11.9 \pm 7.1 \\
110-130\end{array}$ & $\begin{array}{c}148.9 \pm 27 \\
100-220\end{array}$ & $\begin{array}{c}145.8 \pm 17.7 \\
150-180\end{array}$ & $\begin{array}{c}128.9 \pm 18.2 \\
100-160\end{array}$ & $\begin{array}{c}140.5 \pm 20.9 \\
100-1900\end{array}$ & 8.29 & $<0.003$ \\
\hline $\begin{array}{l}\text { DBP(mmHg) } \\
\text { Range }\end{array}$ & $\begin{array}{c}74.7 \pm 5.1 \\
70-80\end{array}$ & $\begin{array}{c}87.9 \pm 14.7 \\
70-130\end{array}$ & $\begin{array}{c}88.4 \pm 10.1 \\
70-100\end{array}$ & $\begin{array}{c}81.5 \pm 11.7 \\
70-110\end{array}$ & $\begin{array}{c}83.2 \pm 9.5 \\
60-100\end{array}$ & 5.1 & $<0.001$ \\
\hline
\end{tabular}


Table (3): Biochemical characteristics of the studied subjects

\begin{tabular}{|c|c|c|c|c|c|c|c|}
\hline variable & $\begin{array}{c}\text { Group } 1 \\
\text { Mean } \pm \text { SD }\end{array}$ & $\begin{array}{c}\text { Group } 2 \\
\text { Mean } \pm \text { SD }\end{array}$ & $\begin{array}{c}\text { Group } 3 \\
\text { Mean } \pm \text { SD }\end{array}$ & $\begin{array}{c}\text { Group } 4 \\
\text { Mean } \pm \text { SD }\end{array}$ & $\begin{array}{c}\text { Group } 5 \\
\text { Mean } \pm \text { SD }\end{array}$ & $\begin{array}{c}\text { F test } \\
(\text { ANOVA) }\end{array}$ & $P$ value \\
\hline $\begin{array}{l}\text { FBS(mg/dl) } \\
\text { Range }\end{array}$ & $\begin{array}{c}92.7 \pm 14.2 \\
78-120\end{array}$ & $\begin{array}{c}95.4 \pm 15.4 \\
80-125\end{array}$ & $\begin{array}{c}95.4 \pm 12 \\
75-115\end{array}$ & $\begin{array}{l}224 \pm 59 \\
141-300\end{array}$ & $\begin{array}{c}232.9 \pm 66.9 \\
136-393\end{array}$ & 60.3 & $<0.001$ \\
\hline $\begin{array}{l}\text { PBG(mg/dl) } \\
\text { Range }\end{array}$ & $\begin{array}{c}119.1 \pm 13.9 \\
99.3-160\end{array}$ & $\begin{array}{c}122.5 \pm 9.4 \\
105-140\end{array}$ & $\begin{array}{c}130.3 \pm 13.2 \\
110-153\end{array}$ & $\begin{array}{c}345.5 \pm 1.3 \\
200-550\end{array}$ & $\begin{array}{c}350.5 \pm 94.2 \\
220-500\end{array}$ & 71.7 & $<0.001$ \\
\hline $\begin{array}{l}\text { Cholesterol } \\
\text { Range }\end{array}$ & $\begin{array}{c}158.6 \pm 19.8 \\
120-188.4 \\
\end{array}$ & $\begin{array}{c}213.3 \pm 46 \\
162-300 \\
\end{array}$ & $\begin{array}{c}217.4 \pm 60.8 \\
119.3-350.6 \\
\end{array}$ & $\begin{array}{c}221.4 \pm 52 \\
153-320 \\
\end{array}$ & $\begin{array}{c}226.3 \pm 53 \\
114.8-304.7 \\
\end{array}$ & 6.29 & $<.0 .003$ \\
\hline $\begin{array}{l}\text { TG } \\
\text { Range }\end{array}$ & $\begin{array}{l}99.4 \pm 24 \\
60.3-163\end{array}$ & $\begin{array}{l}116.7 \pm 44 \\
75.5-267\end{array}$ & $\begin{array}{l}121.8 \pm 41 \\
51-198.5\end{array}$ & $\begin{array}{c}208.6 \pm 77 \\
113.4-400\end{array}$ & $\begin{array}{l}247.3 \pm 146 \\
76.2-788.6\end{array}$ & 12.7 & $<0 . .001$ \\
\hline $\begin{array}{l}\text { HDL } \\
\text { Range }\end{array}$ & $\begin{array}{c}43.1 \pm 13 \\
23.7-92\end{array}$ & $\begin{array}{c}43.9 \pm 5.7 \\
27-43\end{array}$ & $\begin{array}{c}34.7 \pm 6.7 \\
21-49\end{array}$ & $\begin{array}{c}40.3 \pm 8.3 \\
30-57\end{array}$ & $\begin{array}{c}36.2 \pm 6.4 \\
19-49\end{array}$ & 3.6 & 0.008 \\
\hline $\begin{array}{l}\text { LDL } \\
\text { Range }\end{array}$ & $\begin{array}{l}95.5 \pm 20 \\
54-127.5\end{array}$ & $\begin{array}{c}131.4 \pm 50.7 \\
70-230\end{array}$ & $\begin{array}{c}163.4 \pm 50.1 \\
80.7-257\end{array}$ & $\begin{array}{l}135 \pm 45.6 \\
63.7-215\end{array}$ & $\begin{array}{c}168 \pm 53.9 \\
49.6-251-9\end{array}$ & 7.75 & $<.0 .001$ \\
\hline $\begin{array}{l}\text { TGIHDL } \\
\text { Range }\end{array}$ & $\begin{array}{c}2.28 \pm 7 \\
1.3-4.424\end{array}$ & $\begin{array}{c}2.96 \pm .8 \\
1.027-4.8\end{array}$ & $\begin{array}{c}3.73 \pm 1.6 \\
1.5-7.62\end{array}$ & $\begin{array}{c}4.95 \pm 2 \\
1.14-8.84\end{array}$ & $\begin{array}{c}6.1 \pm 2.2 \\
1.55-9.69\end{array}$ & 16.5 & $<.0 .001$ \\
\hline
\end{tabular}

Table (4): Parameter of glucose homeostasis of the studied subjects

\begin{tabular}{lccccccc}
\hline Variable & $\begin{array}{c}\text { Group 1 } \\
\text { Mean } \pm \text { SD }\end{array}$ & $\begin{array}{c}\text { Group 2 } \\
\text { Mean } \pm \text { SD }\end{array}$ & $\begin{array}{c}\text { Group 3 } \\
\text { Mean } \pm \text { SD }\end{array}$ & $\begin{array}{c}\text { Group 4 } \\
\text { Mean } \pm \text { SD }\end{array}$ & $\begin{array}{c}\text { Group 5 } \\
\text { Mean } \pm \text { SD }\end{array}$ & $\begin{array}{c}\text { F test } \\
(\text { ANOVA) }\end{array}$ & P value \\
\hline Insulin & $5.6 \pm 1.4$ & $6.1 \pm 2.1$ & $6.5 \pm 2.1$ & $6.3 \pm 1.98$ & $9.9 \pm 3.8$ & \multirow{2}{*}{9.38} & $<0.001$ \\
Range & $2.92-7.566$ & $3.133-9.551$ & $2.95-10.839$ & $3.96-10.22$ & $3.523-15.35$ & & \\
\hline IR & $1.24 \pm 0.33$ & $1.35 \pm 0.39$ & $1.52 \pm 0.55$ & $3.3 \pm 1.2$ & $5.8 \pm 2.6$ & 42.19 & $<0.001$ \\
Range & $0.62-1.86$ & $0.82-1.96$ & $0.59-3.07$ & $1.57-5.96$ & $1.47-10.46$ & & \\
\hline HBA1C & $5.8 \pm 0.4$ & $6.3 \pm 0.4$ & $6.4 \pm 0.6$ & $8.1 \pm 1.1$ & $8.6 \pm 0.8$ & 53.7 & $<0.001$ \\
Range & $5.32-6.5$ & $5.3-6.9$ & $5.7-8.3$ & $6.4-10.12$ & $7.5-10.7$ & & \\
\hline
\end{tabular}

Table (5): Frequency of IR in different groups

\begin{tabular}{|c|c|c|c|c|c|c|c|}
\hline IR & Group 1 & Group 2 & Group 3 & Group 4 & Group 5 & $\overline{X^{2}}$ & P value \\
\hline$>2.5$ & $\begin{array}{ll}0 & 0.0\end{array}$ & $\begin{array}{ll}0 & 0.00\end{array}$ & 5.3 & 1578.9 & $\begin{array}{ll}18 & 94.7\end{array}$ & \multirow{2}{*}{73.012} & \multirow{2}{*}{$<0.001$} \\
\hline$<2.5$ & 100 & $19 \quad 100$ & 1894.7 & 21.1 & 5.3 & & \\
\hline
\end{tabular}

Table (6): Correlation between TG/HDL and HOMA-IR among studied groups

\begin{tabular}{ccccc}
\hline Groups & HOMA-IR & TG/HDL & $\mathbf{r}$ & $\mathbf{p}$ \\
\hline $\mathbf{1}$ & $1.24 \pm 0.33$ & $2.28+7$ & 0.5 & $>0.05$ \\
$\mathbf{2}$ & $1.35 \pm 0.39$ & $2.96+.8$ & 0.014 & $>0.05$ \\
$\mathbf{3}$ & $1.52 \pm 0.55$ & $3.73+1.6$ & 0.54 & $>0.05$ \\
$\mathbf{4}$ & $3.3 \pm 1.2$ & $4.95+2$ & 0.31 & $<0.05$ \\
$\mathbf{5}$ & $5.8 \pm 2.6$ & $6.1+2.2$ & 0.29 & $<0.05$ \\
\hline
\end{tabular}

\section{DISCUSSION}

Insulin resistance is defined clinically as a condition in which the body produces insulin but does not use it effectively ${ }^{[4]}$. There are many methods of evaluation of insulin resistance, among which the hyperinsulinemic euglycemic clamp technique is considered as the "gold standard" to assess insulin sensitivity; however, it was complicated to operate and time-consuming which, limited its use in clinical and epidemiological studies. Other evaluation methods of insulin resistance, such as the HOMA-IR of minimal model and steadystate model, and fasting glucose and insulin ratio $(\mathrm{G} / \mathrm{I})$, are more complex, time-consuming, and expensive ${ }^{[11]}$.

Predicting insulin sensitivity in normoglycemic individual is important as DM intervention program are more likely to be successful at this stage rather than after development of impaired glucose tolerance .Most studies have investigated predictor of insulin resistance, however, almost all studies have included people with IGT and diabetes 
rather than normoglycemic individual in general population.

Currently, one of the priorities in medicine is prevention and considering the health problems with which we live The prevention of CVD and of the associated factors peak in the health system ${ }^{[12]}$.

The evidence suggests that IR probably precedes the onset of CVD, conditions in which there are metabolic Inflammation and thrombosis disorders. Many factors increase the risk for a subject to develop IR including genetic predisposition and sedentary lifestyle, in addition to other chronic diseases associated with this condition such as obesity, diabetes and atherosclerosis. Considering that prevention is the top priority, we must find and identify the patient who acquires or is at risk of developing IR prior to the onset of the disease in order to delay or prevent its onset ${ }^{[13]}$.

For daily clinical practice, it is necessary to use easily applied measurements in the general population for detection of insulin resistance ${ }^{[14]}$.

Due to the association that exists between dyslipidemia and IR, one of the indices that has been used to evaluate the ratio is the atherogenic index for TGL/HDL because it has been shown that obese individuals frequently present IR and alterations in lipid metabolism such as elevated concentrations of TG-rich lipoproteins and other cholesterol particles ${ }^{[15]}$.

In addition, TG content in liver ${ }^{[16]}$ and muscle tissues is a determining factor for the development of IR. These findings support the important role played by TGs in $\mathrm{IR}^{[17]}$.

This study aimed to develop simple prediction on clinical tool evaluating insulin resistance. In clinical settings, it would be useful to identify individuals with insulin resistance using only routinely collected blood test results such as triglyceride and high-density lipoprotein cholesterol. Hence, we proposed the prediction of insulin resistance by the ratio of TG and HDL-C.

In our study, there was significant difference concerning Serum Cholesterol with highest value in diabetic complicated group (group 5) that was correlated with the study of ${ }^{[12]}$ who reported that there was significant difference between serum cholesterol and insulin resistance among diabetic and non diabetic group.
In our study, there was significant difference concerning serum TG with highest level among group 5, Mean \pm SD $(247.3 \pm 146)$ $(p=0.001)$ that was correlated with studies of ${ }^{[18}$, ${ }^{12]}$ who reported that IR presented with high TG level and this related to a reduced insulin effect in subjects with insulin resistance may result in excessive adipose tissue lipolysis and increased flux of free fatty acids to the liver, which may drive up hepatic triglyceride synthetic rates.

In our study, there was significant difference concerning Serum LDL with higest level among group 5, with Mean \pm SD (168 \pm 53.9) that was correlated with the studies of ${ }^{[19]}$ who reported that HOMA-IR was associated with increase LDL and these were due to insulin up regulates LDL receptor Activity and increases the fractional catabolic rate of LDL apoB and causes a modest reduction in LDL cholesterol levels in those with high LDL levels.

In our study, there was significant difference concerning Serum HDL with the lowest level among group 5 with the Mean \pm SD (36.2 \pm 6.4$)$ that was correlated with the studies of ${ }^{(\mathbf{1 8}, \mathbf{1 2})}$ who reported that HOMA-IR was associated with decrease HDL and this was due to Diminished activity of (lipoprotein lipase) LPL which may result in excessive transfer of triglycerides from triglyceride-rich chylomicrons and VLDL particles in exchange for cholesterol esters from HDL particles, thus reducing levels of HDL cholesterol.

The results of our study showed a significant association between TG/HDL ratio and IR, which translates into the possibility that the elevated TG/HDL ratio suggests the presence of IR. With cut-off point 2.5 were similar to study of ${ }^{[12]}$ and MESYAS (Metabolic Syndrome in Active Subject in Spain) study conducted by Cordero et al in Spain) which revealed the presence of the TG/HDL ratio as part of the MetS and provides cut-off points of $>2.75$ in males and $>1.65$ in females ${ }^{[20]}$.

However, there were conflicting such as that reported by Sumner et al showing that the TG/HDL ratio is not a good marker of IR in African-American subjects with one of the explanations being racial differences and the lipoprotein lipase activity responsible for the metabolism of $\mathrm{TG}^{[21]}$. 
Previous studies had used different cut-off values of TG/HDL to predict insulin resistance; however, the result was inconclusive. The cut off point for TG/HDL appear to vary among different ethnic groups. Appear to be 3.0 for Hispanic white and Mexican American and 2.0 non Hispanic black. The threshold of TG/HDL appear to depend on ethnicity ${ }^{(22)}$. However, no studies have specifically compared accuracy of TG/HDL with and without other clinical and demographic factors in predicting insulin resistance in Egyptian adult. SO in our work we depend nearest ethnicity for cocasian race which is Hispanic white.

In our study, there was significant difference concerning Serum insulin with highest level among group 5 with Mean \pm SD $(9.9 \pm 3.8)$ that were correlated with the studies of $[18,12]$ who reported that that there were significant difference between serum insulin and insulin resistance among diabetic and non diabetic groups.

In our study, there was significant difference concerning fasting and postprandial glucose with Mean \pm SD $(232.9 \pm 66.9)$ and $(345.5 \pm 1.3)$ respectively that were correlated with the study of ${ }^{(\mathbf{1 2})}$ who reported that HOMAIR was associated with increase fasting and postprandial glucose. Insulin resistance related more strongly to postprandial deficiency than to the fasting state and this related to Mealinduced Insulin Sensitization (MIS), normally occurs in response to a mixed meal, and absence of MIS is based on inability of the liver to secrete HISS (Hepatic Insulin Sensitizing Substance) in response to insulin. The argument has been made that HDIR (HISS-dependent insulin resistance) could account for the primary endocrine defect in the pre-diabetic and diabetic state. Absence of MIS results in altered postprandial nutrient processing away from skeletal muscle and toward lipid production by liver and fat cells.

In our study, there was significant difference concerning HBA1C with higest value in group (5) with Mean \pm SD $(8.6 \pm 0.8)$ $(\mathrm{P}=<0.001)$ that was correlated with the study of ${ }^{(23)}$ who reported that HOMA-IR was associated with increase HBA1C $(p=0.037)$. This was due to feedback between glucose concentration (the major stimulus for insulin release) and beta-cell insulin secretion, in insulin resistance found in most type 2 diabetic patients there is decrease the capacity to secrete additional amounts of insulin to compensate for the insulin resistance.

In our study, there was significant difference concerning systolic blood pressure \& diastolic blood pressure, among diabetic groups than non diabetic groups that were correlated with studies of ${ }^{(\mathbf{1 8}, 12)}$ who reported that IR presented with higher systolic and diastolic arterial pressure compared to the individuals without IR. and this related to dyslipidemia associated with insulin resistance.

In our study, there was significant difference concerning body mass index with, Mean \pm SD $(30.4 \pm 4.1) \quad(p=0.001)$ and waist circumference with, Mean \pm SD $(121 \pm 6.2)$ $(\mathrm{P}=<0.001)$ among diabetic than non diabetic groups and these were correlated with studies of $[18,12]$ who reported that IR presented with high BMI and high waist circumference and this related to Increased inflammatory cytokines and decreased adiponectin concentrations have been associated with obesity, intra-abdominal fat accumulation.

Currently, when discussing a patient with IR, we think immediately of the presence of the metabolic syndrome entity, and we know that our duty is to identify it. We must begin the preventive process for the risk of developing chronic degenerative diseases, especially CVD, the leading cause of comorbimortality.

It becomes imperative to establish criteria for early identification of risk factors associated with not only the MetS but also one of its main components, IR because early identification will prevent the development of any chronic diseases with which it interacts. According to the results obtained in this study, to determine an elevated TG/HDL ratio allows the assessment of the onset of treatment to reduce IR as well as to initiate prevention and appropriate treatment of dyslipidemia. In turn, reduction of TG levels is a consideration. This latter aspect is based on the reports of its beneficial effects in the presence of CVD, Already shown in several studies.

Our study has several limitations that should be considered. First, the causal and temporality between the TG/HDL ratio and IR cannot be established with certainty due to the study design. Therefore, there is no assurance that 
elevated TG/HDL ratio is a risk factor for the development of IR. Second, the low conformation of the group without IR may be related to the size of our sample

\section{CONCLUSION}

There is a significant association between HOMA- IR and TG/HDL ratio suggesting that elevated TG/HDL ratio can be used to predict the presence of insulin resistance. We recommend future studies on large number of diabetic to get more information about insulin resistance to clarify factors affecting it .Addition of other marker to augment validation of insulin resistance.

\section{REFERENCES}

1. Rother KI: "Diabetes treatment bridging the divide". The New England Journal of Medicine; 2007;356 (15): 1499-501.

2. Wild S, Roglic G, Green A, Sicree R, King H: "Global prevalence of diabetes: Estimates for the year 2000 and projections for 2030". Diabetes Care; 2004;27 (5): 1047-53.

3. Mottillo S, Filion KB, Genest $\mathbf{J}$, et al.,: The metabolic syndrome and cardiovascular risk a systematic review and meta-analysis. J Am Coll Cardiol.; 2010;56:1113-1132.

4. National Diabetes Information Clearinghouse: Insulin Resistance and Prediabetes. 2013.

5. Muniyappa $\mathbf{R}$, Lee $S$, Chen $H$, et al,: Current approaches for assessing insulin sensitivity and resistance in vivo: advantages, limitations, and appropriate usage. Am J Physiol Endocrinol Metab.; 2008;294: E15-26.

6. Bonora E, Targher G, Alberiche M, et al.,: Homeostasis model assessment closely mirrors the glucose clamp technique in the assessment of insulin sensitivity: studies in subjects with various degrees of glucose tolerance and insulin sensitivity. Diabetes Care. 2000;23: 5763.

7. Van Linthout $S$, Spillmann F, Schultheiss HP, et al.,: Tschope C. High-density lipoprotein at the interface of type 2 diabetes mellitus and cardiovascular disorders. Curr Pharm Des.l 2010;16:1504 1516.

8. Tohidi M, Hatami M, Hadaegh et al.,: Triglycerides and triglycerides to high-density lipoprotein cholesterol ratio are strong predictors of incident hypertension in Middle Eastern women. J Hum Hypertens. 2011;25, 484-491.

9. Waist Circumference and Cardio metabolic Risk: A consensus statement from shaping and American health: Association for weight management and obesity prevention; NAAOS, the Obesity Society; The American Society for Nutrition and American Diabetes Association. Diabetes Care; 2007;30: 1641-165.

10. Ramachandran A, Snehalatha C, Salini J, Vijay V: Use of glimpride and insulin sensitizer in the treatment of type 2 DM-A study in Indian, JAPI. 2004;52: 459-463.

11. Traub ML: "Assessing and treating insulin resistance in women with polycystic ovarian syndrome," World Journal of Diabetes, 2011;vol. 2, (3): 33-40.

12. Antonio Gonzalez-Chavez, Luis Ernesto Simental-Mendia, and Sandra ElizondoArgueta: Elevated triglycerides/HDLcholesterol ratio associated with insulin resistance CirCir; 2011;79: 115-119.

13. Rader DJ (2007): Effect of insulin resistance, dyslipidemia and intra-abdominal adiposity on the development of cardiovascular disease and diabetes mellities. Am J Med 2007; 120 (suppl 1):S12-S18.

14. Simental-Mendia LE, Rodriguez-Moran M, Guerrero-Romero F: The product of fasting glucose and triglycerides as surrogate for identifying insulin resistance in apparently healthy subjects. Metab Syndr Relat Disord; 2008;6: 299-304.

15. Chan DC, Watts GF, Barrett PH, et al.: Markers of triglyceride-rich lipoprotein remnant metabolism in visceral obesity. Clin Chem; 2002;48: 278-283.

16. Ryysy L, Hakkinen AM, Goto $T$, et al.: Hepatic fat content and insulin action on free fatty acids and glucose metabolism rather than insulin absorption are associated with insulin requirements during insulin therapy in type 2 diabetic patients. Diabetes; 2000;49: 749-758.

17. Krssak M, Petersen KF, Bergeron R, et al.: Intramuscular glycogen and intramyocellular lipid utilization during prolonged exercise and recovery in man: a $13 \mathrm{C}$ and $1 \mathrm{H}$ nuclear magnetic resonance spectroscopy study. J Clin Docrinol Metab; 2000;85: 748-754.

18. Jui-Kun Chiang, Ning-Sheng Lai, Malcolm Koo, et al.: Predicting insulin resistance using the triglyceride-to-high-density lipoprotein cholesterol ratio in Taiwanese adult. Cardiovasc Diabetol. 2011; 10: 93. Published online 2011; October 17. doi: 10.118614752840-10-93

19. Christian Anderwald, Marietta Stadler, Alain Golay, et al.: Impact of family history on relations between insulin resistance, LDL cholesterol and carotid IMT in healthy adults. Heart 2010; 96: 1191-1200.

20. Cordero A, Laclaustra $M$, Leon $M$, et al.: Prehypertension is associated with insulin 
resistancestate and not with an initial renal function impairment. A Metabolic Syndrome in Active Subjects in Spain (MESYAS). Am J Hypertens 2006; 19: 189 - 196.

21. Sumner AE, Finley KB, Genovese DJ, et al.: Fasting triglyceride and the triglyceride-HDL cholesterol ratio are not markers of insulin resistance in African Americans. Arch Intern Med; 2005;165: 1395-1400.

22. Mclaugh T, Abbasi F, Cheal K, et al.: use of metabolic markers to identify over weight individuals who are insulin resistance. Ann Intern med: 2003;139: 802-809.

23. Caroline M. Sanz, Jean-Bernard Ruidavets, Vanina Bongard, et al.: Relationship Between Markers of Insulin Resistance, Markers of Adiposity, HbA1c, and Cognitive Functions in a Middle-Aged Population-Based Sample: the MONA LISA study. Diabetes Journals. Org Print ISSN: 2012;0149-5992. Online ISSN: 1935-5548 